\title{
Mit livs OL-eventyr \\ - det personlige møde med De Olympiske Lege Af Johnny Wøllekar
}

Det var gået stærkt, meget stærkt for den odenseanske svømmepige Jytte Hansen. I 1946 var hun blevet meldt ind i Svømmeklubben Frem, og nu kun to år senere var hun på vej til De Olympiske Lege. Allerede ved de danske mesterskaber i 1948 overraskede hun alt og alle ved at besejre den tidligere mester Grethe Sørensen på både 100 meter og 200 meter. Det udløste sensationelt en billet til De Olympiske Lege i London, som blev den odenseanske teenagepiges første store udlandsrejse. I interviews med blandt andet Odense Stadsarkiv har Jytte Hansen fortalt, at det var en nervøs og meget forventningsfuld skolepige på bare 15 år - og med særdeles god appetit - der steg på toget i Odense.

\section{OLYMPIADE LONDON 1948}

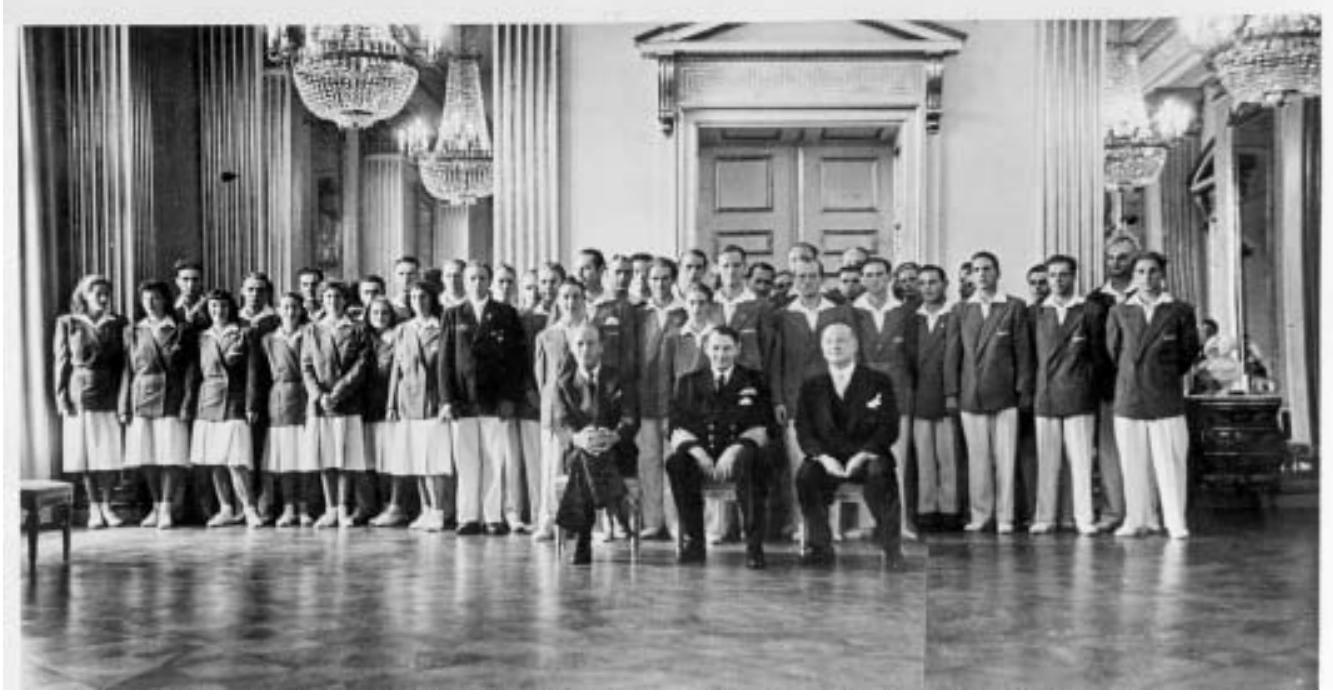

De danske OL-deltagere i audiens på Amalienborg i 1948. Blandt sportsfolkene var også de seks odenseanske deltagere (Odense Stadsarkiv). 


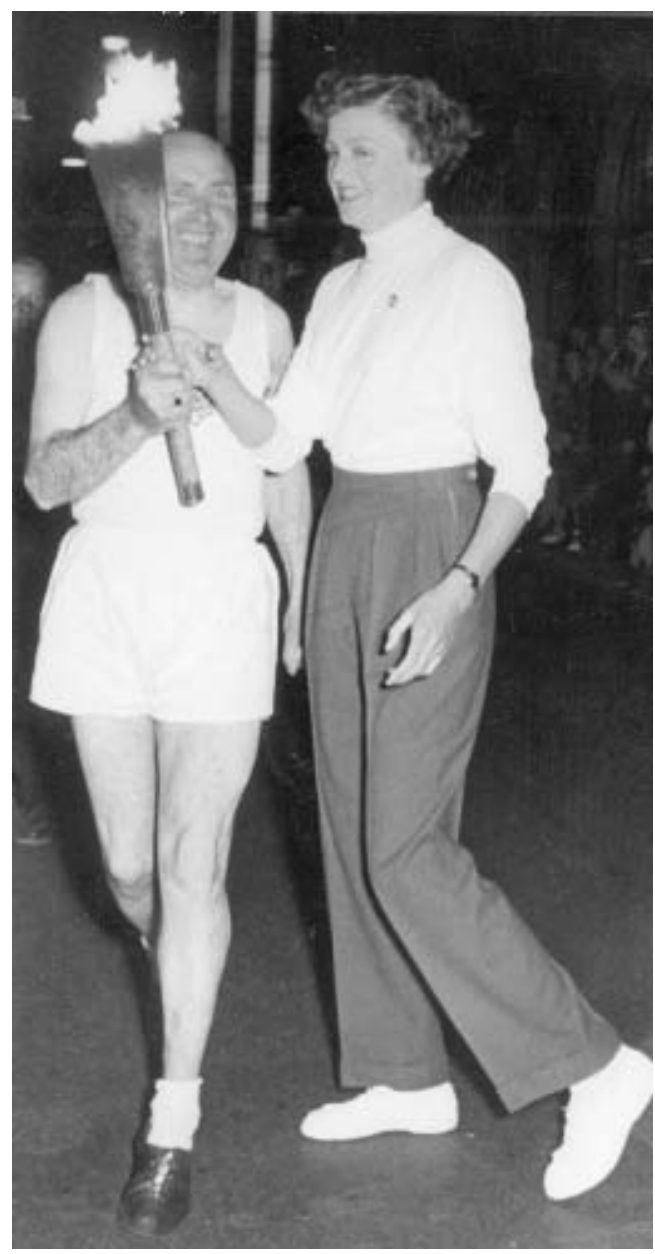

Svømmepigen Jytte Hansen fär overrakt den olympiske fakkel af loberen Aksel Jensen, og hun skulle i 1952 lobe turen ind til Odenses centrum. Begge sportsfolk deltog iflere Olympiske Lege. Jytte Hansen reprosenterede således de danske farver $i$ London (1948), Helsingfors (1952) og Melbourne (1956). To gange kvalificerede hun sig til finalen i 200 meter bryst og var med en femteplads i Helsingfors kun 2/100 sekund fra en medalje (Odense Stadsarkiv).

»Jeg havde ingen anelse om forplejningen, så min mor stod på perronen og læssede mad i massevis ind gennem vinduet, bl.a. nogle bøffer, en stor skål rødgrød, tre flasker mælk og til sidst en stor hjemmebagt kage ...« $\ll^{1}$

Den lille pige fra provinsen var benovet og vidste intet om, hvad der ventede hende. Hvordan skulle hun forholde sig? Mon hun fik noget at spise på turen? Den megen mad, der blev læsset ind gennem togvinduet og stablet op i kupeen, gav de andre OL-deltagere et billigt grin. Og skolepigen med den glubende appetit blev flov.

Men svømmepigens kvaler var ikke ovre endnu. Da den danske delegation på sin vej til London ankom til Liverpool, kom den landskendte journalist Gunnar » $\mathrm{Nu} \ll$ Hansen hen og hilste og spurgte: »Hvad er det, jeg hører, Jytte? Spiser du al pigernes mad? « Og det hele blev selvfølgelig heller ikke bedre, da Berlingske Tidende på forsiden bragte en historie om, at den fynske svømmepige selv medbragte boghvedegrød.

I det olympiske svømmebassin gik det dog lidt bedre. Den fynske svømmepige kom overraskende i finalen på 200 meter med sjettebedste tid.

Finalen blev afviklet om aftenen, og det meste af dagen gik Jytte Hansen hvileløst rundt på det college, hvor de danske svømmere var indkvarteret lidt uden for Londons centrum. De andre svømmere og lederen var derimod inde ved det olympiske svømmebassin. Lederen havde lovet at hente hende i god tid, men en time før finalen var der endnu ikke dukket nogen op. Den nervøse svømmepige besluttede derfor at tage bybussen ind til svømmestadion. Hun nåede lige akkurat at sætte sig ind, da en leder dukkede op og fik hende ind $i$ en bil. I susende fart gik det gennem Londons stærkt trafikerede gader, og en halv time før finalen ankom den lille danske delegation til svømmestadion. 
»Da jeg stod på startskamlen og så ned i vandet, var jeg tæt på at kaste op - fordi jeg var køresyg efter en lang og besværlig tur gennem London fra vores hotel til svømmestadion, og derfor blev jeg kun nummer otte $\ll^{2}$

\section{Mødet med De Olympiske Lege}

Historien om svømmepigen Jytte Hansen og hendes møde med De Olympiske Lege er ikke alene fortællingen om en ung pige, der fik en oplevelse for livet. Det er også historien om, hvordan dansk eliteidræt blev håndteret for bare 50 år siden - og dermed indirekte også en afspejling af, hvordan idrætten på godt og ondt forandrede sig gennem det 20. århundrede. Det er historien om idrætten, der blev mere professionel - også på ledelsesplan.

Jytte Hansen, der siden giftede sig til efternavnet Nielsen, deltog ved De Olympiske Lege i London i 1948, i Helsingfors i 1952 og i Melbourne i 1956. Hun har netop fortalt sin personlige OL-historie til Odense Stadsarkiv, der i øjeblikket - med hjælp fra en række frivillige - er ved lave interviews og indsamle materiale fra og om tidligere odenseanske OL-deltagere. Det er OL-deltagernes egne, personlige oplevelser og mødet med De Olympiske Lege, der er omdrejningspunkt for denne unders $\varnothing$ gelse, som bl.a. skal være med til at dokumentere de kolossale forandringer, eliteidrætten har gennemgået inden for de seneste 100 år. $^{3}$

\section{Forberedelser}

Hvor meget de enkelte OL-deltagere trænede op til legene, varierede fra idrætsgren til idrætsgren. I svømning og andre

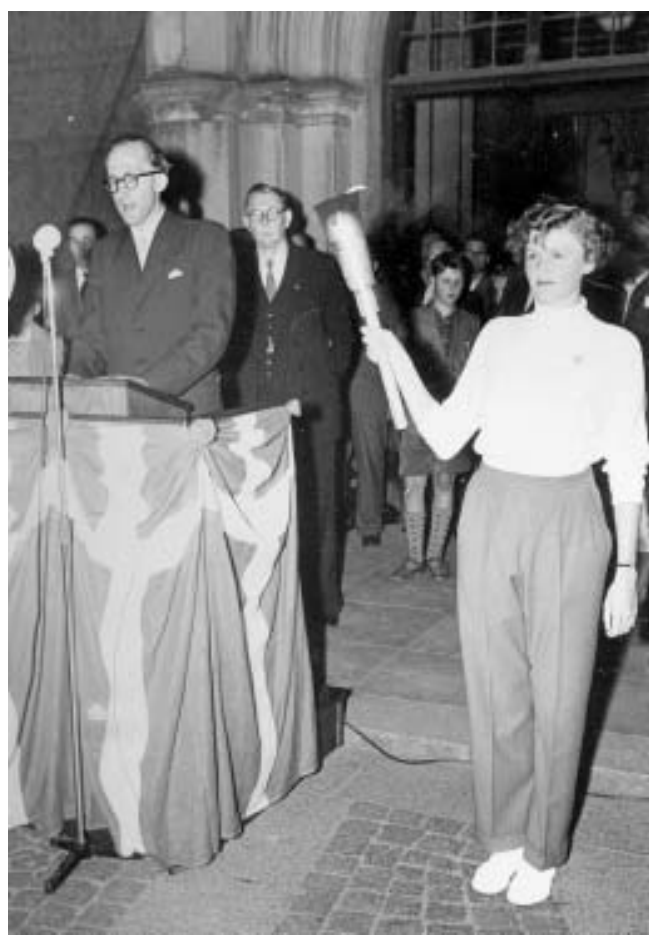

Den odenseanske svфmmer Jytte Hansen fik 1952 aren af at lobe sidste tur med den olympiske fakkel på dens tur gennem Odense og ind til Flakhaven $i$ byens centrum, hvor der foregik en mindre olympisk ceremoni med et par taler. »Mens der blev holdt taler, skulle jeg stå med faklen havet højt. Jeg lod den glide lidt ned $i$ hånden, hvor jeg holdt fast $i$ noerheden af en jernkant under flammen. Jernet var brandvarmt - men jeg ville ikke give slip på faklen eller på anden måde lave opmorksomhed omkring mig. Så jeg måtte bare holde fast og bide smerterne i mig", husker Jytte Hansen, der fik brandsår på tommel og pegefinger ved den lejlighed (Odense Stadsarkiv).

individuelle idrætsgrene blev der til tider trænet hver dag, mens f.eks. boldspillerne »kun« havde tre træningsaftener. Sammenlignet med i dag var træningsmængden dog generelt betydeligt mindre. 


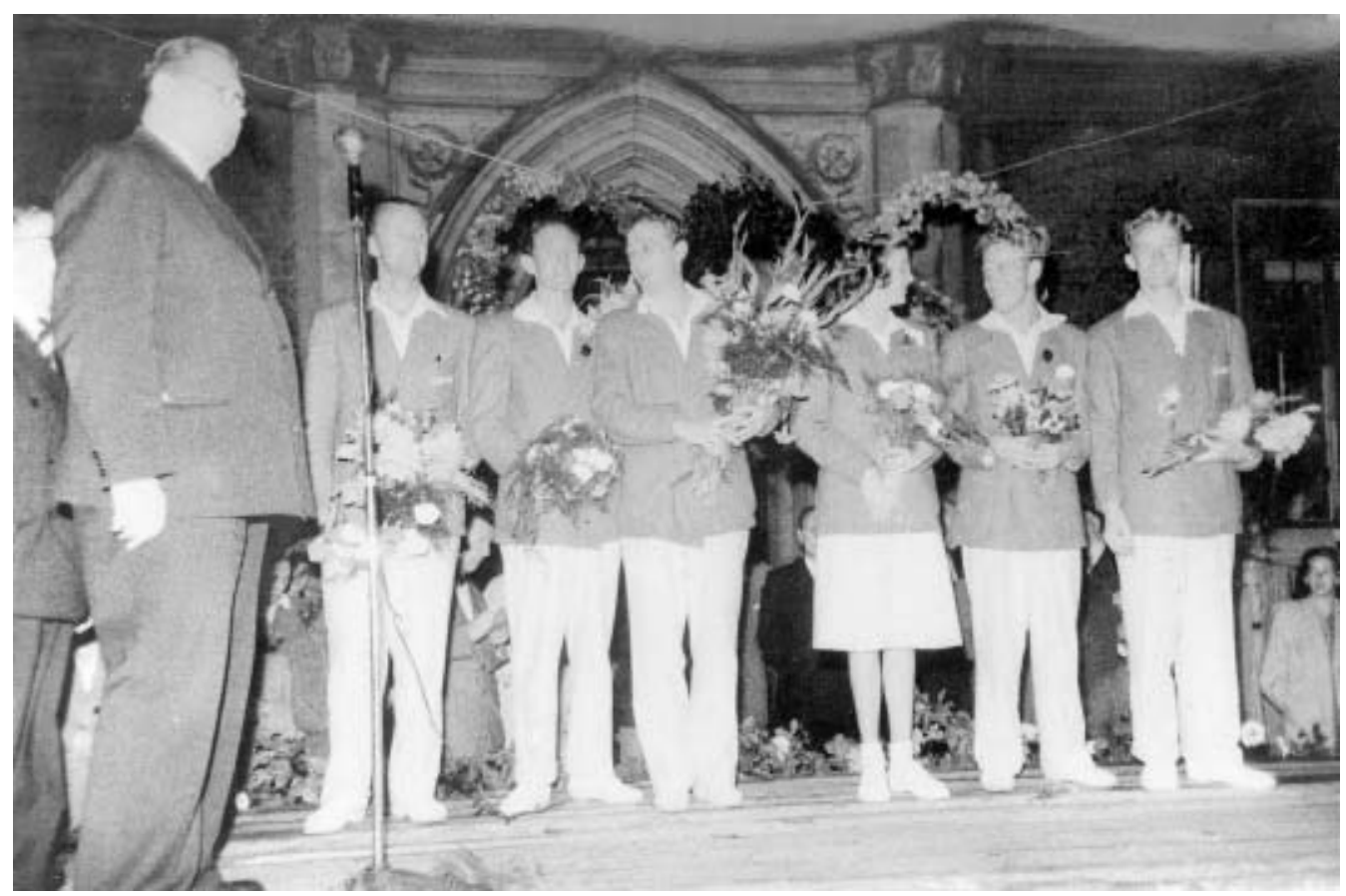

De odenseanske OL-deltagere samlet på Flakhaven (Odenses centrum) i 1948. Fra venstre ses borgmester I. Vilh. Werner, roeren Bernhard Jensen, roeren Eivind Hansen, fodboldspilleren Jørgen Leschly Sфrensen, svømmeren Jytte Hansen og lфberen Ingvard Hansen (Odense Stadsarkiv).

Kajakroeren Knud Ditlevsen, der var med ved De Olympiske Lege i 1948, fortæller:

»Træningsmængden var forbavsende lille. Jeg kan se, at jeg i olympiadeåret 1948 roede godt $850 \mathrm{~km}$ på et år. I dag, hvor jeg er 77 år, ror jeg mindst $2.000 \mathrm{~km}$ på et år. Der var heller ikke noget, der hed styrketræning. Det havde jeg simpelthen ikke kræfter til. I året 1948 arbejdede jeg som havnearbejder på Odense Havn. Det var jo med hænder og skulder. Vi bar alting, så kræfter havde jeg nok af, om end jeg ikke var noget muskelbundt, men jeg var åbenbart sej. Derfor blev det også $10 \mathrm{~km}$, der blev min bedste disciplin $\ll{ }^{6}$
Som de fleste andre havde svømmeren Jytte Hansen ingen personlig træner og klarede sig meget selv - heller ikke senere, da hun som voksen forberedte sig til OL i Helsingfors og Melbourne. Den almindelige klubtræning foregik om vinteren i Odense Svømmehal og i sommermånederne i byens friluftsbad, hvor hun svømmede blandt børn, der legede, og voksne badegæster, som optog meget af pladsen:

»Dengang trænede man som konkurrencesvømmer måske godt et par tusinde meter om dagen, allerhøjst 3.000, tre-fire gange om ugen. Op til de større stævner blev der trænet to gange om dagen - afhængig af, hvordan jeg kunne få det indpasset med 


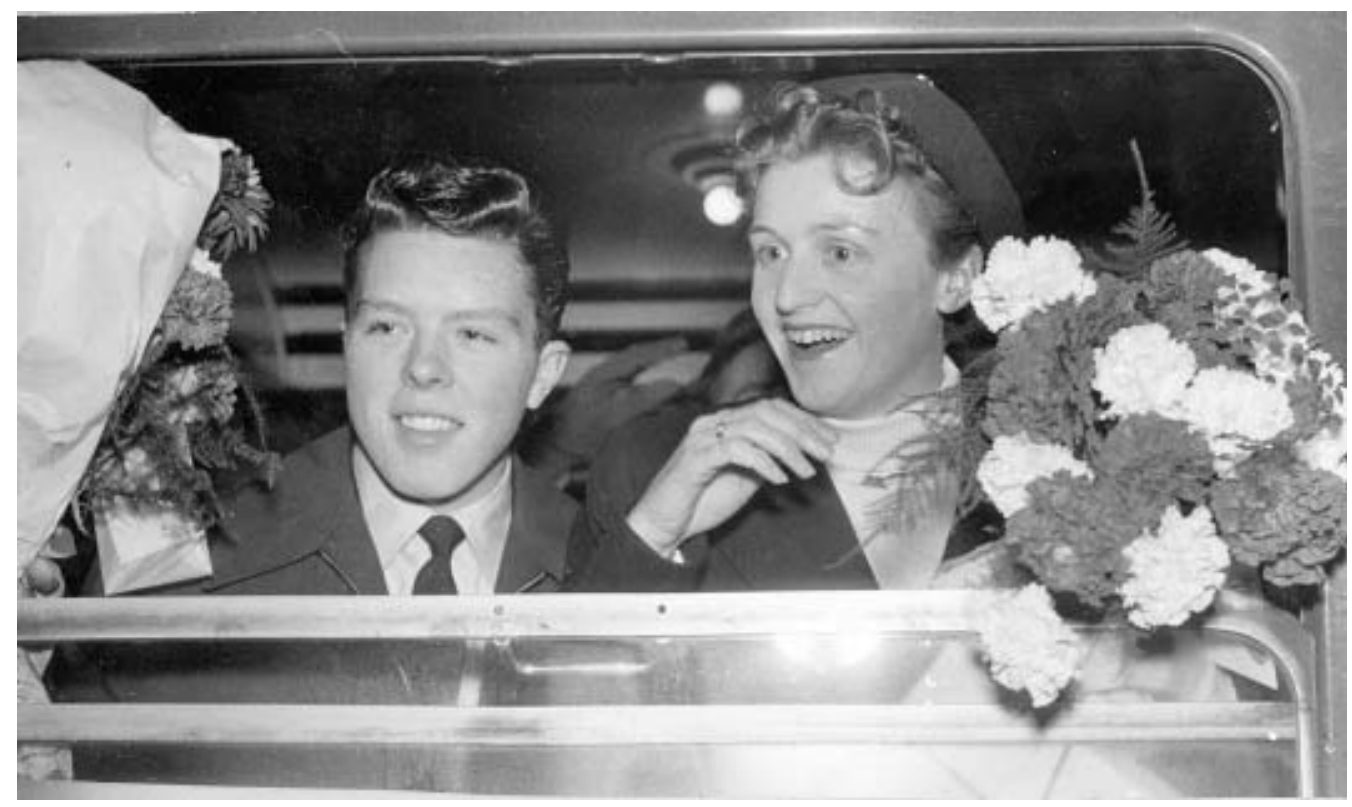

Afrejse fra Odense Banegård. De odenseanske OL-deltagere på vej til OL i Melbourne $i$ 1956. Svømmeren Jytte Hansen (senere gift Nielsen) og cykelrytteren Palle Lykke (Jensen) vinker farvel fra togkupeen den 11.11.1956. Turen gik først til Kфbenhavn og derfra med fly til Stockholm, Honolulu og Australien (Odense Stadsarkiv).

arbejdet. Det er jo noget mindre, end hvad de unge gør i dag ... Jeg havde fuldtidsjob, så jeg trænede først om morgenen, inden jeg gik på arbejde og så direkte fra arbejde igen. Men tit og ofte måtte jeg jo kæmpe for en plads i bassinet, for der var jo ikke nogle deciderede baner lagt ud . $^{7}$

Og Jytte Hansen fortæller videre:

»Dengang skulle vi slås om træningstimerne både i svømmehallen og i friluftsbadet. Jeg husker tydeligt, da friluftsbadet på grund af kulde endnu ikke var lukket op, men var det eneste sted, jeg kunne træne. Så ringede jeg til badeinspektøren for at få lov at komme og træne. Men det kunne ikke lade sig gøre, så jeg klatrede over pigtråden og klædte om bag et par buske og hoppede i bassinet. Vandet var 12 grader, og mine ben føltes som isstøtter, men der var ingen vej uden om. Og når Assenstoget kørte forbi på jernbanen tæt ved, vidste jeg, at jeg havde klaret 20 minutter i det isnende vand $\ll .8$

I månederne op til Melbourne-legene blev Jytte Hansens muligheder for at træne i f $\varnothing$ debyen Odense fuldstændig spoleret, da byens eneste svømmehal lukkede på grund af reparationer.

»Efter svømmehallens lukning tog jeg nogle gange til Svendborg, men det blev ærlig talt for besværligt, og det er jo heller ikke sjovt at skulle træne, mens et halvt hundrede mennesker muntrer sig i bassinet «.

Derfor rykkede den fynske svømmepige teltpælene op for en tid og flyttede til hovedstaden. Det betød et midlertidigt 


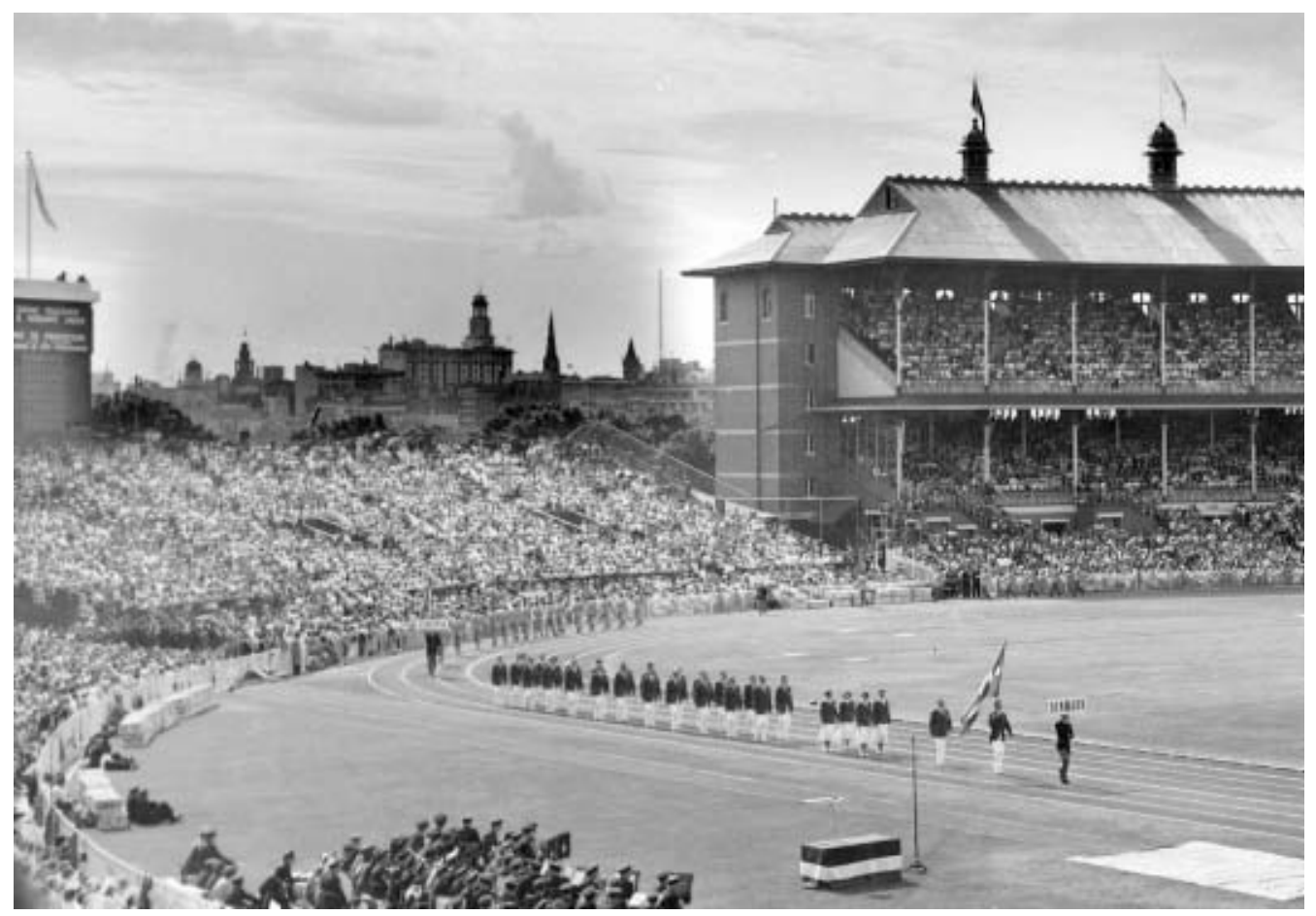

Det danske OL-holds indmarch på det olympiske stadion i Melbourne i 1956 (Odense Stadsarkiv).

farvel til familien og kæresten, men det var ikke det eneste afsavn, OL-deltagere måtte lide.

\section{Afsavn for deltagelsen}

Optakten til OL-deltagelsen var ofte ganske ydmyg i forhold til i dag. De fleste af de OL-deltagere, som er blevet interviewet, havde fuldtidsjob på det tidspunkt, hvor de blev udtaget, trænede og hvor de deltog i De Olympiske Lege. Det gjorde forberedelserne både besværlige og kostbare. Nogle havde imødekommende arbejdsgivere, der gav dem fri, men de blev dog trukket i $\emptyset$.

Fodboldspilleren Jørgen Leschly Sørensen, der repræsenterede Danmark ved De Olympiske Lege i 1948, har fortalt:
»Jeg havde stadigvæk fuldtidsarbejde hele tiden. Og den gang var det endog sådan, at vi, der kom fra provinsen, vi kunne ikke få tabt arbejdsfortjeneste. Jeg sendte bl.a. afbud til en landskamp i protest ... det var måske lige ved at koste min deltagelse ved olympiaden $\ll^{4}$

Senere - i 1960'erne - var der dog enkelte idrætsfolk, der nød særlige privilegier. Det gjaldt blandt andre cykelrytteren Peder Pedersen, der deltog i OL i 1964, 1968 og 1972. Han har fortalt:

»Da jeg blev ansat ved politiet, nød jeg godt af statens regler, som gav mulighed for frihed med løn, når man blev udtaget til VM og OL.

Da jeg i 1968 skulle til De Olympiske 
Lege i Mexico, var jeg netop blevet ansat ved politiet og fik fri i hele syv uger, så jeg kunne forberede mig på højden derovre. Derimod da jeg var ved militæret, kunne jeg mærkeligt nok ikke få fri til at deltage ved VM og andre store begivenheder, uden man skulle straffes for det. Det skulle betales med »eftertjeneste«. Da de andre blev hjemsendt, måtte jeg pænt blive nogle ekstra dage, som svarede til det antal dage, jeg havde haft fri.$^{5}$

Endnu i mellemkrigsårene måtte OL-deltagerne selv skaffe en del af rejseudgifterne, hvilket skete gennem en særlig rejsefond. Den odenseanske maratonløber Aksel Jensen, der deltog ved De Olympiske Lege i Antwerpen i 1920, fortæller i sine erindringer:

»Otte dage efter afrejste vi så til Antwerpen via Esbjerg-Harwich. De københavnske deltagere afrejste om morgenen kl. 9. Kl. 12.30 ankom toget til Odense, hvor jeg kom med. Vi idrætsmænd fandt hurtigt hinanden, og så gik det videre ad Esbjerg til. Her skulle vi afholde en opvisning til fordel for vort rejsefond. Der blev afholdt forskellige løb og $\varnothing$ velser, blandt andet 100 meter, 400 meter, 3 km, højdespring, længdespring og stangspring samt kast. Desværre var det kun en lille, men interesseret tilskuerskare, der var mødt, så det gav ikke det forventede store overskud «. ${ }^{9}$

Også ved De Olympiske Lege i Paris i 1924 deltog Aksel Jensen. Forud var han dog kommet på kant med Dansk Atletikforbund, der ville have $»$ den smilende fynbo « til at lægge sin træning om. Det ville Aksel Jensen imidlertid ikke, og så meddelte forbundet, at han ikke skulle regne med at blive udtaget til OL:
»Men så en dag kom der brev fra B.T. i København, om jeg dog ikke alligevel nok ville deltage i Paris. Bladet ville stå som den $\varnothing$ konomiske garant og fandt, at det var synd, hvis Danmark ikke fik sin chance i maratonløbet, ét af de steder, hvor den var størst. Jeg svarede dertil, at jeg nu ikke havde så stor lyst til at deltage, og at jeg heller ikke havde passet min træning i den sidste tid, så nu ville jeg helst være fri. Men presset fra forskellige sider, blandt andet fra min forening, gav jeg til sidst efter og lovede at tage med til Paris ... Jeg rejste for B.T.s regning for penge, der var kommet ind gennem bladets indsamling og uden for forbundets skærmende omsorg $\ll^{10}$

De $\varnothing$ konomiske forhold for de aktive blev skridt for skridt forbedret, men endnu i 1940'erne og 1950'erne var det helt almindeligt, at OL-deltagerne ikke fik nogen som helst erstatning for tabt arbejdsfortjeneste, når turen gik til De Olympiske Lege. Kajakroeren Knud Ditlevsen siger det sådan:

»Arbejdsgiveren havde grinet sig ihjel, hvis jeg havde bedt om fri til at gå ud og ro. Nej, der var ikke noget, som hed tabt arbejdsfortjeneste eller fri til store opgaver dengang. Det eneste vi fik betalt, det var rejserne og fortæring. Der var ingen erstatning for tabt arbejdsfortjeneste. Det kendte vi simpelt hen ikke. Jeg regner med, at min olympiade-deltagelse kostede mig godt $1.000 \mathrm{kr}$. Omregnet til nutidskroner var det mange penge $\ll .{ }^{11}$

Det var ikke blot $\varnothing$ konomisk, at OL-deltagerne somme tider måtte lide afsavn for at gøre drømmen om OL-deltagelse til virkelighed. Da De Olympiske Lege i München 1972 stod for døren, meldte fodboldspille- 
ren Jack Hansen afbud til klubholdet B1913's tur til Jylland og Gran Canaria for i stedet at træne til OL.

»Mit afbud til turen skete ud fra devisen om, at det med at komme sydpå på en ferietur, det kan man altid komme. Anderledes med en OL-deltagelse. Her er der mange ting, der skal falde på plads, for at man får chancen for deltagelse. På det tidspunkt kunne jeg ikke forudse, om jeg nogen sinde fik en anden chance - og i bedste fald ville det først være om fire år «. ${ }^{12}$

\section{Åbningsceremonien}

Hele den pompøse åbningsceremoni efterlod hos flere OL-deltagere et uudsletteligt indtryk. De fleste synes, at åbningen var en stor og spændende oplevelse. Jytte Hansen siger:

»I London sad jeg på tilskuerpladserne, fordi jeg skulle svømme næste dag, og i Helsingfors ankom svømmerne først dagen efter åbningsceremonien. Men i Melbourne var jeg med, og det var en ubeskrivelig oplevelse. Da vi kom ind på stadion, gik der et sug og en stor glæde igennem én, samtidig med at jeg fik tårer i øjnene. At opleve dette sus fra et overfyldt stadion var helt fantastisk «. ${ }^{13}$

Det var dog ikke alle, som deltog i åbningen. Fodboldspilleren Jack Hansen, der var med i München 1972, fortæller:

»Vi fodboldspillere var ikke med ved åbningen, da vi skulle spille kamp næste dag. Det var helt op til hver enkelt, om man ville deltage. Jeg kan ikke huske, om der var nogen af dem fra fodboldholdet, der deltog. Det var drønvarmt i München på det tidspunkt, så ikke mange havde lyst til at stå en hel dag i bagende sol, når vi skulle $\mathrm{i}$ aktion dagen efter. Godt nok var vi glade amatører, men lidt seriøse omkring forberedelserne til de forestående kampe var vi dog. Så det blev valgt fra, men vi så det i fjernsynet $\ll .{ }^{14}$

For cykelrytteren Peder Pedersen blev åbningsceremonierne - ikke mindst den i 1972, hvor han var fanebærer - noget helt særligt.

»Jeg havde aldrig forestillet mig, at jeg kunne få tildelt jobbet som fanebærer. Hvis jeg hjemmefra var blevet tilbudt det, så havde jeg måske sagt nej. Det er jo marginalerne, der afgør, om man vinder en medalje. Jeg mente faktisk, at jeg havde gode chancer for at hente en medalje, og så kunne det skade min præstation, hvis jeg skulle gå med flaget og deltage i den lange ceremoni. Men da jeg først fik tilbudet, kunne jeg umuligt afslå det. Det er jo ganske få, der får lov til at prøve $\operatorname{det} \ll .^{15}$

\section{Det danske sammenhold}

De fleste interviewede er enige om, at der herskede et godt sammenhold blandt de danske OL-deltagere, men hvorvidt det var bedre hos danskerne end hos andre nationer ved OL-deltagerne ikke. De danske deltagere havde ikke altid noget med hinanden at gøre i det daglige, men når der var en dansker i konkurrence - og hvis det var muligt - så tog man selvfølgelig hen og heppede.

»Så kom nationalismen jo op i en, og så var man henne og hyle og skrige. Det hørte sig ligesom til. Men det havde også noget at gøre med at få tiden til at gå«, siger fodboldspilleren Jack Hansen. 


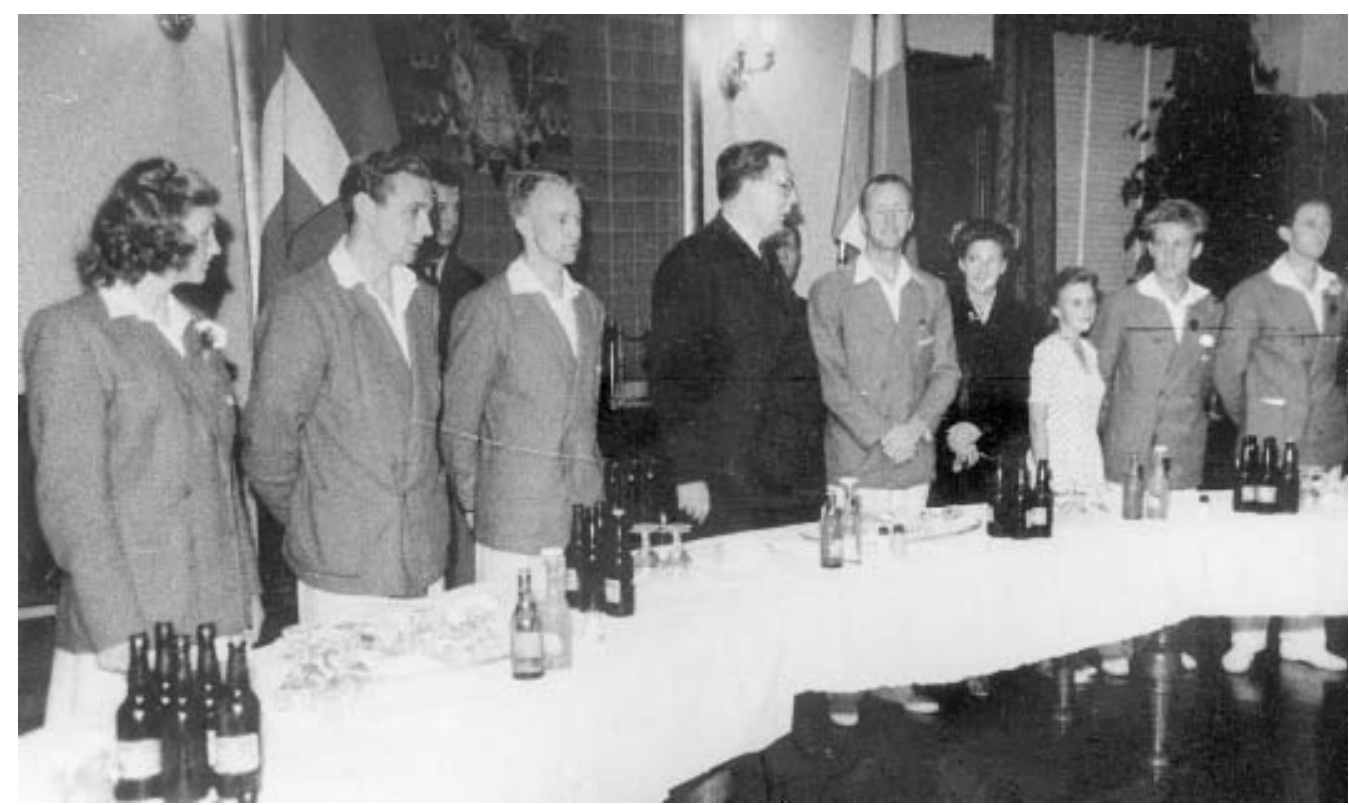

De odenseanske OL-deltagere til modtagelse på Odense Rådhus den 18. august 1948. Fra venstre ses Jytte Hansen (gift Nielsen), Jørgen Leschly Sørensen, Ingvard Nielsen, Odenses borgmester I. Vilh. Werner, Bernhard Jensen, Knud Ditlevsen og Eivind Hansen (Odense Stadsarkiv).

Også mødet med folk fra de andre nationer i den olympiske by får ofte roser med på vejen. Jytte Hansen oplevede, at samværet ved OL i London og i Helsingfors lod en del tilbage at $\varnothing$ nske, da deltagerne ikke alle var samlet. Derimod var livet i Melbournes olympiske by i 1956 helt ekstraordinært:

»Den olympiske by bestod af flere hundrede rækkehuse, hvoraf vi danskere havde tre i herre- og et halvt i kvindelejren til vor disposition. I hele lejren boede 5-600 idrætsdeltagere og ledere, og vi havde alle de bekvemmeligheder, som hører til en hel by: posthus, koncertsal, vaskeri, hospital, forretninger af alle slags, frisørsaloner og træningsbaner til atletikfolkene. Kort sagt: Den olympiske by var en komplet forstad til Melbourne ... Kammeratskabet i lejren var enestående. Aftenerne var hyggelige, stilige englændere og iltre negre tog mangen en dyst, da »rock'n'roll «-feberen rasede. Jeg kommer som sand dansker så let til at tænke på vor kantine, som vi delte med de $\varnothing$ vrige nordiske deltagere. Og jeg tror, jeg kan udtrykke det bedst ved at sige, at jeg aldrig gennem længere tid har spist så fyrsteligt, som vi gjorde i Melbourne. Hver dag blev der budt på alt, hvad en dansk gourmet kunne $\varnothing$ nske $\operatorname{sig}{ }{ }^{16}$

Nogle deltagere fik i den olympiske by venner for livet - både blandt de danske og de udenlandske aktive.

Derimod kunne forholdet til lederne af og til være lidt anstrengt. Det var jo ikke de trænere og ledere, som trænede de aktive hjemme i klubberne, der var med til OL. Kajakroeren Knud Ditlevsen fortæller: 
»Forholdet mellem os aktive var førsteklasses. Vi havde jo Karen Hoff fra Ålborg til at holde os nede på jorden. Den sindige jyske pige, der ikke var spor imponeret over at vinde en guldmedalje. Derimod blev forholdet til lederne lidt anstrengt, fordi Bernhard Jensen [anden odenseansk roer] - der i øvrigt vandt sølv - forlod lejren og tillod sig at tage på hotel sammen med sin kæreste. Det passede ikke lederne, og gav en hel del ballade - med det resultat, at Bernhard holdt op med at ro. Man kunne ikke finde på at sætte sig ned og snakke sammen ${ }^{17}{ }^{17}$

\section{Højdepunktet i karrieren}

For mange af de interviewede var det noget helt specielt at deltage ved De Olympiske Lege. En oplevelse for livet. Rejser til det store udland var endnu i efterkrigsårene ikke hverdagskost, og en rejse til f.eks. OL i Melbourne i Australien var en drømmerejse, når de aktive samtidig måtte mellemlande på Hawaii, hvor man blev i to dage. Deltagerne fik deres horisont udvidet.

»Min deltagelse i tre olympiader, var så afgjort højdepunkterne i min tid som aktiv ... For mig var det en enestående, ja uforglemmelig oplevelse at være OL-deltager. Forberedelserne forud for hvert OL var en udfordring. En udfordring til gennem flittig træning at nå et stort mål. Der var mange sure træningstimer med stopuret som en partner, som gjorde hverdagen uharmonisk og absolut ikke særlig spændende, men i dag er jeg lykkelig for, at viljen til at opnå det højeste for en idrætsudøver var den stærkeste. Det var prisen værd. Når jeg i dag tænker tilbage på min deltagelse i OL, tegner der sig et portræt af rige menneskelige oplevelser manifesteret i samværet med sportsfolk fra alverdens lande «. ${ }^{18}$
Mange tidligere OL-deltagere regner De Olympiske Lege for det absolut største i deres idrætskarrierer, også selv om OLkonkurrence rent sportsligt rangerede lavere end f.eks. verdensmesterskaber. Cykelrytteren Peder Pedersen siger:

»Inden for cykelsporten rangerer verdensmesterskaberne højere sportsligt end De Olympiske Lege. Verdensmesterskabet rummer mere cykelsport end ved et OL, hvor der er begrænsninger for, hvor mange ryttere, som må deltage fra hvert land. Potentielle medaljevindere bliver faktisk udelukket fra at deltage ved OL, da hvert land kun må stille med et par ryttere. Ved verdensmesterskaberne kan alle, der har kvalificeret sig starte. Men som begivenhed og til at huske tilbage på, så er De Olympiske Lege klart det største «. ${ }^{19}$

Der kan peges på flere grundlæggende årsager til, at idrætsudøvere regner De Olympiske Lege for noget helt særligt. At OL kun bliver afholdt hvert fjerde år, er sikkert en del af forklaringen. Men også sammenholdet, det storslåede ved arrangementet og mødet med de mange aktive fra andre idrætsgrene spiller ind. At gå rundt $\mathrm{i}$ den olympiske by og møde idrætsfolk fra hele verden og måske også nogle af ens egne idoler - det er i hvert fald, hvad der ofte bliver trukket frem, når tidligere OL-deltagere fortæller om mødet med De Olympiske Lege.

\section{Sammenfatning}

Når man læser og hører om deltagernes møde med De Olympiske Lege, fornemmer man hurtigt, hvor stor og afgørende betydning for folks liv OL-deltagelse fik. Ikke sådan at forstå, at OL-deltagelse vendte rundt på alting, der kom også en hverdag igen. Men mange fik gode ople- 
velser og minder med hjem i kufferten, også selv om de aldrig var i nærheden af at vinde en medalje.

Når de danske OL-deltagere med Dannebrog i spidsen marcherede ind på det olympiske stadion og mærkede bruset fra de mange tilskuere, fik mange aktive en klump i halsen. Ord som »en utrolig oplevelse« eller »mit livs eventyr « går ofte igen $\mathrm{i}$ interviewene.

En kronologisk læsning af de mange interviews fortæller ikke bare historien om den enkelte idrætsudøvers oplevelser.
Samlet giver de også et spejlbillede af, hvordan dansk eliteidræt langsomt blev mere velorganiseret - blev mere professionel. Hvor idrætsfolkene i 1940'erne og 1950'erne mere eller mindre var overladt til sig selv ved forberedelser til OL, ja sågar under selve OL, så begyndte træningslejre, specieltrænere og lignende at dukke op i 1960 'erne og 1970 'erne. ${ }^{20}$ De aktive blev udtaget tidligere, så der var god tid til at få den optimale forberedelse, ligesom det også blev nemmere at få fri til at forberede sig på De Olympiske Lege.

\section{Noter}

1. Olsen, S. (1999), p. 15.

2. Ibid. samt interview.

3. Alle interviewede fik stillet nogenlunde samme spørgsmål, så resultaterne kunne sammenlignes og tematiseres. Unders $\varnothing$ gelsen er inspireret af Birthe Pedersen upublicerede speciale Olympisme - og danske idratsfolksdeltagelse i de moderne olympiske lege, der blev indleveret ved Odense Universitet i 1990.

4. Interview med Knud Ditlevsen.

5. Interview med Jytte Hansen.

6. Pedersen, P. I. (2000).

7. Pedersen, B. (1990), bd. II, p. 32-33. Citatet er lettere sprogligt bearbejdet.
8. Interview med Peder Pedersen.

9. Jensen, A. (1927), p. 22.

10. Ibid.

11. Interview med Knud Ditlevsen.

12. Interview med Jack Hansen.

13. Interview med Jytte Nielsen (født Hansen).

14. Interview med Jack Hansen.

15. Interview med Peder Pedersen.

16. Manuskript til foredrag i Jytte Hansens arkiv (Odense Stadsarkiv).

17. Interview med Knud Ditlevsen.

18. Se note 16.

19. Interview med Peder Pedersen.

20. Ibid.

\section{Litteraturliste}

Jensen A. Femten aar som løber (København, 1927). Kristensen P. (red.) De olympiske. Biografi af danske OL-deltagere 1896-1996 (København, 1996).

Olsen S. Til OL med mors madforsyninger. I: Politiken d. 10.1.1999, 1. sektion, p. 15.

Pedersen B. Olympisme - og danske idratsfolks del- tagelse i de moderne olympiske lege (upublicerede speciale fra Odense Universitet i 1990).

Pedersen P. I. Fra Svømmer til Golfer. I: Idrætten på Fyn nr. 2, juni 2000.

Wøllekær J. Odense i bevagelse (Viborg, 2001). 